\title{
Where is sugarcane cropping expanding in the brazilian cerrado, and why? A case study
}

\author{
MURILO R. DE ARRUDA ${ }^{1,2}$, KEN E. GILLER ${ }^{3}$ and MAJA SLINGERLAND ${ }^{3}$ \\ ${ }^{1}$ Embrapa Amazônia Ocidental, Rodovia AM-010, Km 29, (Estrada Manaus/ \\ Itacoatiara), Caixa Postal 319, 69010-970 Manaus, AM, Brazil \\ ${ }^{2}$ Programa de Pós-Graduação em Agronomia Tropical, Universidade Federal do Amazonas, Faculdade \\ de Ciências Agrárias, Av. Rodrigo Octavio J. Ramos, 6200,69080-900 Manaus, AM, Brazil \\ ${ }^{3}$ Plant Production Systems, Wageningen University, P.O. Box 430, 6700AK Wageningen, The Netherlands
}

Manuscript received on May 20, 2015; accepted for publication on October 13, 2015

\begin{abstract}
Sugarcane growing area in Brazil sharply expanded between 2000 and 2010 due to the increasing world demand for sugar and ethanol. Since this expansion of sugarcane is said to occur in areas covered by degraded pastures, it is likely not threatening the environment or food production. In order to verify this assumption, we investigate at farm and field levels which types of land use sugarcane cropping replaced between 2005 and 2010 and the reasons for farmers shifting or not shifting to sugarcane, as a case study in two counties in the state of Goiás. Within the studied period, sugarcane cropping expansion was related to large farms, lower risk perceived by farmers, and higher profitability compared with soybean and beef cattle-raising. For smallholders, particularly dairy farmers, the need to comply with the set-aside rules under Brazilian Forest Code (Código Florestal Brasileiro) made a shift to sugarcane less attractive, as it would have forced them to reduce farm cultivable area, with loss of incomes. From 30,408 ha under sugarcane surveyed, $45.7 \%$ had used to be pastures, $31 \%$ had previously been pastures rotated with soybean and maize, and $23.3 \%$ had been cropped exclusively with soybean or maize.
\end{abstract}

Key words: land use change, dairy farming, pastures, cropping, small farmers.

\section{INTRODUCTION}

The area cropped with sugarcane in Brazil expanded by 4.3 million ha in 2000 to 9.1 million ha in 2011 (IBGE 2012). This sharp increase can be attributed to three factors: the introduction of flex-fuel car engines in 2003, which can run with any proportion of gasoline and ethanol; restrictions imposed on export of subsidized sugar from the European Union (WTO 2005), opening new markets for

Correspondence to: Murilo Rodrigues de Arruda

E-mail: murilo.arruda@embrapa.br
Brazilian sugar; and the increasing price of sugar in the international market (Trostle et al. 2011). Yet aside from these benefits, sugarcane is an intrinsically appealing crop: it is a flexible crop that allows companies to shift production in the direction of more sugar or more ethanol depending which one presents better prices; at the same time, sugarcane production generates a profitable surplus of electricity through bagasse burning, which is delivered to the country's national grid (Seabra and Macedo 2011). At the national level, sugarcane expansion can be argued to have had little impact 
on land use and land use change, as it occupies only $2.4 \%$ of Brazil farming land (IBGE 2012). However, at local levels this scenario is quite different, as sugarcane can occupy up to $70 \%$ of a county's land area devoted to farming, such as in Sertãozinho, in the state of São Paulo (CANASAT 2013), competing for land with other agricultural activities as soybean, maize and cattle raising.

Although São Paulo State embraces $60 \%$ of Brazil's sugarcane area and accounts for most of its recent expansion (IBGE 2012), beginning in 2005 sugarcane cropping started to move towards Central Brazil, particularly to the state of Goiás, which is largely covered by the Cerrado biome (IBGE 2012). Cerrado is savannah-type vegetation dominated by extensive flat areas, ideal for mechanization and highly suitable for large scale cropping and cattle-raising due to its soils and climate. As a result, from 204 million ha originally covered by Cerrado vegetation, 99 million ha are currently in use for cropping and pastures (IBGE 2010). High prices for buying and leasing land in São Paulo state (IEA 2012), plus governmental incentives such as subsidized loans and tax exemptions to sugarcane mills in Goiás (Zopelari and Teixeira 2011), are important drivers for its expansion in Goiás. The state has 12.6 million ha of land suitable for sugarcane cropping (excluding areas under natural vegetation), of which 7.8 million ha are under pasture and 4.8 million ha are under crops (Manzatto et al. 2009), mostly soybean and maize. As up to $80 \%$ of the pastures in the Cerrado are degraded to some degree (Barcelos 1996, Miranda 2001) and poorly profitable (Yokoyama et al. 1999) it has been assumed that sugarcane expansion would mostly replace degraded pastures (O Estado de São Paulo 2011a, CGEE 2012). This strong, fast expansion of sugarcane between 2000 and 2011 also raised concerns about its impact on smallholders, who are responsible for $87 \%, 70 \%$, and $58 \%$ of Brazilian production of cassava, beans and milk, respectively (MDS 2009). Therefore, this paper aims to empirically evaluate where sugarcane expansion is taking place and the reasons triggering this shift from the farmers' perspective.

\section{MATERIALS AND METHODS}

\section{SITE DESCRIPTION}

This case study research took place in the counties of Quirinópolis and Gouvelândia counties (Figure 1). The surveyed counties are located in the southwest of Goiás, and cover altogether 460,000 ha of land, dominated by flat areas and well-drained, deep ( $>$ $200 \mathrm{~cm}$ ), sandy clay and clay Rhodic Ferralsols (Dystric, Clayic) or Haplic Ferralsols (Dystric) according to the Brazilian Soil Map (IBGE and EMBRAPA 2001). The climate is dry savannah type (Aw) according to the Köppen classification. There is a hot, rainy summer and a dry, cool winter, with annual average temperature ranging from 20 to $22{ }^{\circ} \mathrm{C}$ (INMET 2012). More than $90 \%$ of the rain $(1,700 \pm 200 \mathrm{~mm}$ annually) occurs between September and April. Traditionally, Quirinópolis and Gouvelândia have been important producers of soybean, maize, beef, and milk, with a total cattle herd of around 367,000 head (IBGE 2012) over the last 40 years. Two sugar mills were built in Quirinópolis near the border with Gouvelândia, county triggering an expansion of 80,800 ha in sugarcane-cropped area between 2006 and 2012 (CANASAT 2013) with plans to crop another 70,000 ha in the future (O Estado de São Paulo 2011b). Although there is no official data, the local extension services office (Emater-GO) estimates that original vegetation covers up to $5 \%(23,000$ ha) in both counties distributed in scattered spots, mostly with no more than one contiguous hectare.

\section{FARMERS AND FARM SURVEYS}

Two field surveys were conducted in both counties. In the first, farmers were interviewed using a semistructured questionnaire between April and June 2009 in order to understand the reasons for their shift 


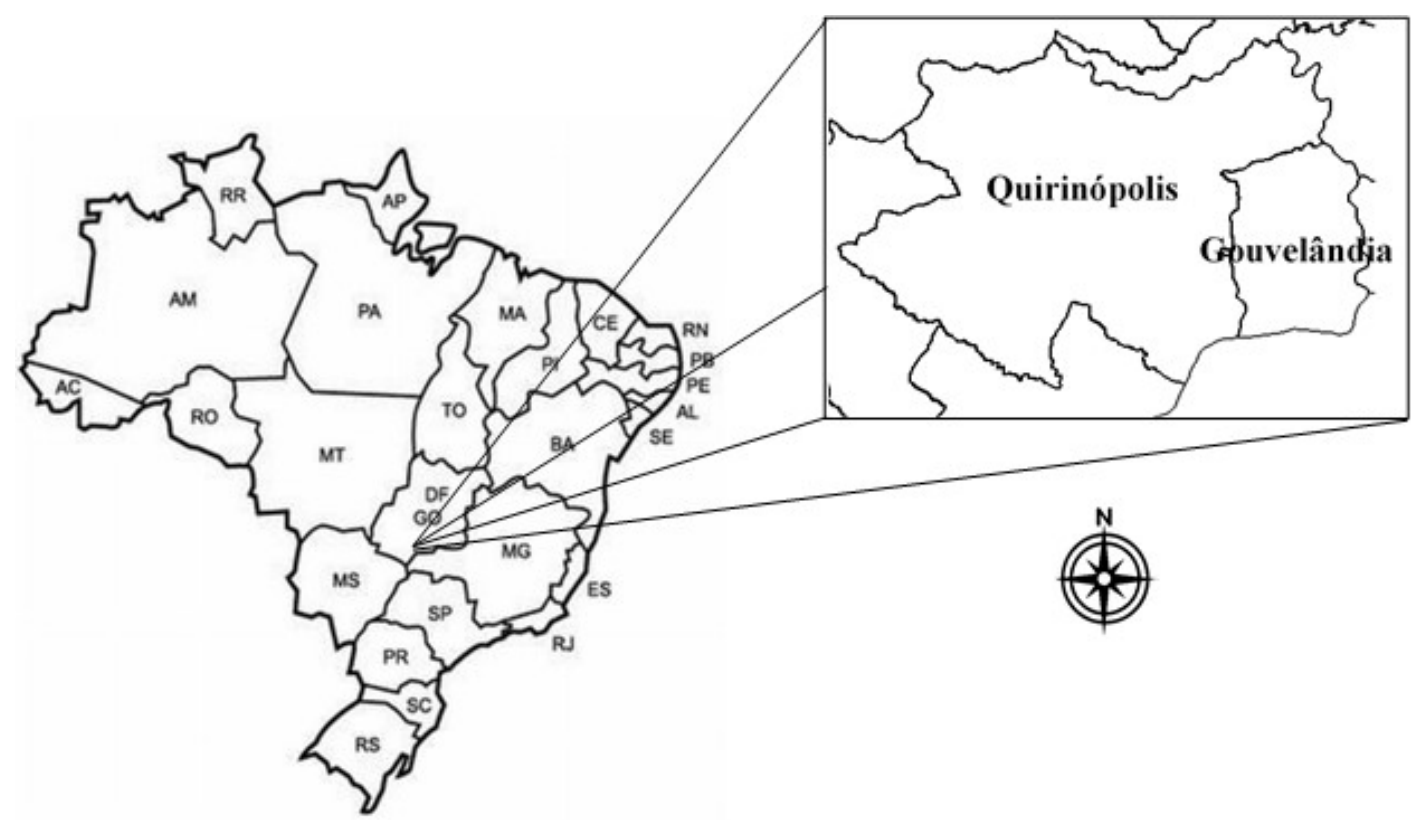

Figure 1 - Location of Quirinópolis and Gouvelândia municipalities, Goiás, Brazil.

or lack of shift to sugarcane cropping. According to a dataset provided by INCRA (Instituto Nacional de Colonização e Reforma Agrária - National Institute for Land Settlement and Agrarian Reform, Brazil), $82 \%$ of the farms $(2,199)$ in Quirinópolis and Gouvelândia have less than 200 ha, accounting for $30 \%(123,603 \mathrm{ha})$ of both counties' total area. The remaining 18\% includes 487 farms covering 299,600 ha. In this study, we define as "small farms" the ones with less than 200 ha in which owners live on the property and have in agriculture their main source of income. Farms smaller than 200 ha that do not fit this definition were considered to be "investor farms" and not included as small farm. Due to the complex logistics involved in this study (large distance between farms, frequent absence of landowners, resistance to being interviewed), we set out to interview a limited number of farmers, 60 , over the 90 days available for this survey. As we were interested in capturing the highest diversity of farmers and their motives, the sampled farmers were distributed over all sub-regions of the counties (namely, Sete Lagoas, Confusão do Rio Preto, Guarirobas, Serra da Fortaleza, Paredão,
Salgado, and Castelo). For each sub-region, a "central farm" was picked randomly; from this farm, neighboring farmers in all directions were visited and interviewed when possible.

The second survey was conducted in January and February 2010, exclusively on farms engaged with sugarcane production in that year in order to establish their land use in terms of sugarcane cropping over the five previous years.

There are no official annual data about pasture area in the studied counties. Therefore, we estimated pasture area indirectly: For each studied year, areas cropped with soybean, maize, and sugarcane plus estimated area covered in natural vegetation $(23,000 \mathrm{ha})$ and infrastructure and urban areas $(10,000 \mathrm{ha})$ were subtracted from the total area of Quirinópolis and Gouvelândia counties (460,000 ha).

\section{RESULTS AND DISCUSSION}

\section{FARMER INTERVIEWS}

Of the 60 farmers targeted by the first field survey, 41 were interviewed; their farms embraced 20,918 ha; 
the other farmers could not be reached or declined to be interviewed. Of the 41 interviewed farmers, 24 were considered small $(<200 \mathrm{ha})$, embracing 2,510 ha in all, while 17 were large farmers, owning 18,408 ha. Individual farms areas ranged from 29 to $6,240 \mathrm{ha}$, all of them under one or more of four agricultural activities: dairy and beef cattle-raising and soybean, maize, or sugarcane cropping (Table I). In general, milk production prevails at small farms while beef cattle and cropping are the main activities at large farms.

Of the interviewed farmers, $54 \%, 17 \%$ and $29 \%$ considered their soil or pasture to be "not degraded," "partially degraded," and "degraded," respectively. Pasture and/or soil degradation was not mentioned by farmers as a reason for land use change; thus, it is unlikely that sugarcane expansion is occurring due to or preferentially over degraded pastures.

The interviewed farmers expressed higher risk perception and lower profitability as reasons to quit soybean and maize cropping and shift to sugarcane cropping. This finding is reinforced by the fact that in both counties soybean was profitable in only seven of the years between 1999 and 2012, whereas in two years (2001 and 2007) incomes and production costs were similar (farmers in principle would have broken even) and another two years (2005 and 2006) showed high financial losses (Figure 2a); maize was profitable in only five and four years in Quirinópolis and Gouvelândia, respectively (Figure 2b), in the same period. As this implies, observing events between 1999 and 2010, sugarcane expansion over (formerly) soybean and maize cropped area was facilitated by a peculiar economic, agronomic, and political context: Between 2003 and 2007, soybean prices on the international market declined (CEPEA 2012), Meanwhile, an economic turmoil caused by a presidential election in 2002 took place, with the perception that new policies would take place causing economic disruption, leaded to capital flight and a large devaluation of the Brazilian currency (the Real) in the following years (BarbosaFilho 2008).

Due to the fall in the real, and the fact that agricultural input prices, such as fertilizers and agrochemicals, are largely US dollar-based,

TABLE I

Area and agricultural activities of the interviewed farmers in the counties of Quirinópolis and Gouvelândia, Goiás, Brazil $(\mathrm{n}=41$, area $=20,918 \mathrm{ha})$.

\begin{tabular}{|c|c|c|}
\hline Area (ha) & Activities & Number of farms \\
\hline \multirow{5}{*}{$<200$} & Dairy cattle & 15 \\
\hline & Dairy and beef cattle & 3 \\
\hline & Dairy cattle and soybean or maize cropping & 1 \\
\hline & Dairy cattle, beef cattle and soybean or maize cropping & 1 \\
\hline & Beef cattle & 4 \\
\hline \multirow{9}{*}{$>200$} & Dairy and beef cattle & 5 \\
\hline & Dairy and beef cattle, sugarcane cropping & 1 \\
\hline & Dairy and beef cattle, sugarcane and soybean or maize cropping & 1 \\
\hline & Dairy and beef cattle, soybean or maize cropping & 2 \\
\hline & Soybean cropping & 1 \\
\hline & Sugarcane cropping & 1 \\
\hline & Beef cattle & 3 \\
\hline & Beef cattle and sugarcane cropping & 1 \\
\hline & Beef cattle, sugarcane, soybean or maize cropping & 2 \\
\hline
\end{tabular}


production costs rose, while soybean productivity collapsed between 2004 and 2006 due to droughts and soybean rust disease (Phakopsora pachyrhizi). This combination of factors over successive years led farmers to perceive sugarcane cropping as less risky than soy. Sugarcane is drought resistant compared to other crops, and to date suffers from no major pests or diseases. Also important is a consortium between the farmers and the sugarcane mills (CONSECANA 2006) that sets sugarcane prices paid to farmers in advance, decreasing uncertainties. For beef cattle farmers, poor profitability was also the main reason to shift to sugarcane, despite the fact that beef, unlike soy, has been low risk (Hecht 1993). According to Kichel et al. (1999) beef productivity in Brazil is on average $31 \mathrm{~kg}$ ha year ${ }^{-1}$, equivalent to a gross income of only USD 90 ha year ${ }^{-1}$ in 2012 (CEPEA 2012). From 2008, due to price recovery, favorable climate, chemical control of soybean rust disease, and resultant increasing soybean productivity and profitability, grain cropping area is showing more resilience in the studied counties (Figure 3). Hence, since sugarcane area is still expanding and there is no land to be deforested, this late expansion has to be occurring over pastures.

Sugarcane cropping has promised higher profitability and relatively lower risk for the landowner, explaining its continuous expansion in the studied counties. However, this promise differs depending on the type of contract made with sugarcane mills: Land can be leased to the sugarcane mill, or the farmer can be an independent supplier of sugarcane. For leased areas, the sugarcane mill is responsible for all operations, from planting to harvesting, in contracts of six to seven years (equivalent to one production cycle of sugarcane or six harvests). There are no costs to the farmer, who receives as payment the equivalent of the total recoverable sugar (TRS) content for $12 \mathrm{t} \mathrm{ha}^{-1}$ (on average; sometimes as high as $15 \mathrm{t}$ $\mathrm{ha}^{-1}$ ) of sugarcane, fixed by contract. Independent suppliers, in contrast, are responsible for all operations except mechanical harvesting; they incur all risks but are paid according to the total amount of sugarcane delivered to the mill based on its TRS content. Under these two systems, we estimate that sugarcane profitability ranged between USD 358 and USD $448 \mathrm{ha}^{-1}$ under land lease (Figure 4a) and USD 1,027 and USD 1,742 for independent suppliers (Figure 4b) during the period 2007-2011, assuming a production cost of USD 1,155 ha year ${ }^{-1}$ for a five-year cycle (Miguel et al. 2011).

None of the small $(<200$ ha $)$ farmers interviewed were cropping or willing to crop sugarcane in the future (themselves or by leasing to mills). They indicated that despite offers from sugarcane mills, it was not tempting for them to shift to sugarcane. This is because in Brazil, sugarcane farmers, whether independent suppliers or leasing their land, are required by mills to follow the Brazilian Forest Code (Código Florestal Brasileiro) so that the mills will not have their image associated with environmental damage. According to the Forest Code, it is mandatory to protect areas close to water sources, such as creeks and rivers, and to maintain $20 \%$ of one's farm under natural vegetation. Since small farms use almost all of their land for farming, in particular for pasture, a considerable area would be lost if they were to shift to sugarcane and adhere to these legal requirements, decreasing their income per unit of area. The interviewed small farmers also mentioned other drawbacks: first, the necessity to sell their cattle herds, with which they have strong cultural and sentimental ties; second, there are recurrent large fires in sugarcane, and so for safety reasons they would have to move with their families to the city, drastically changing their lifestyle; and third, dismantling farm infrastructure, such as fences, roads, and corrals, to allow largescale mechanization of sugarcane might involve too large cost to rebuilt. 

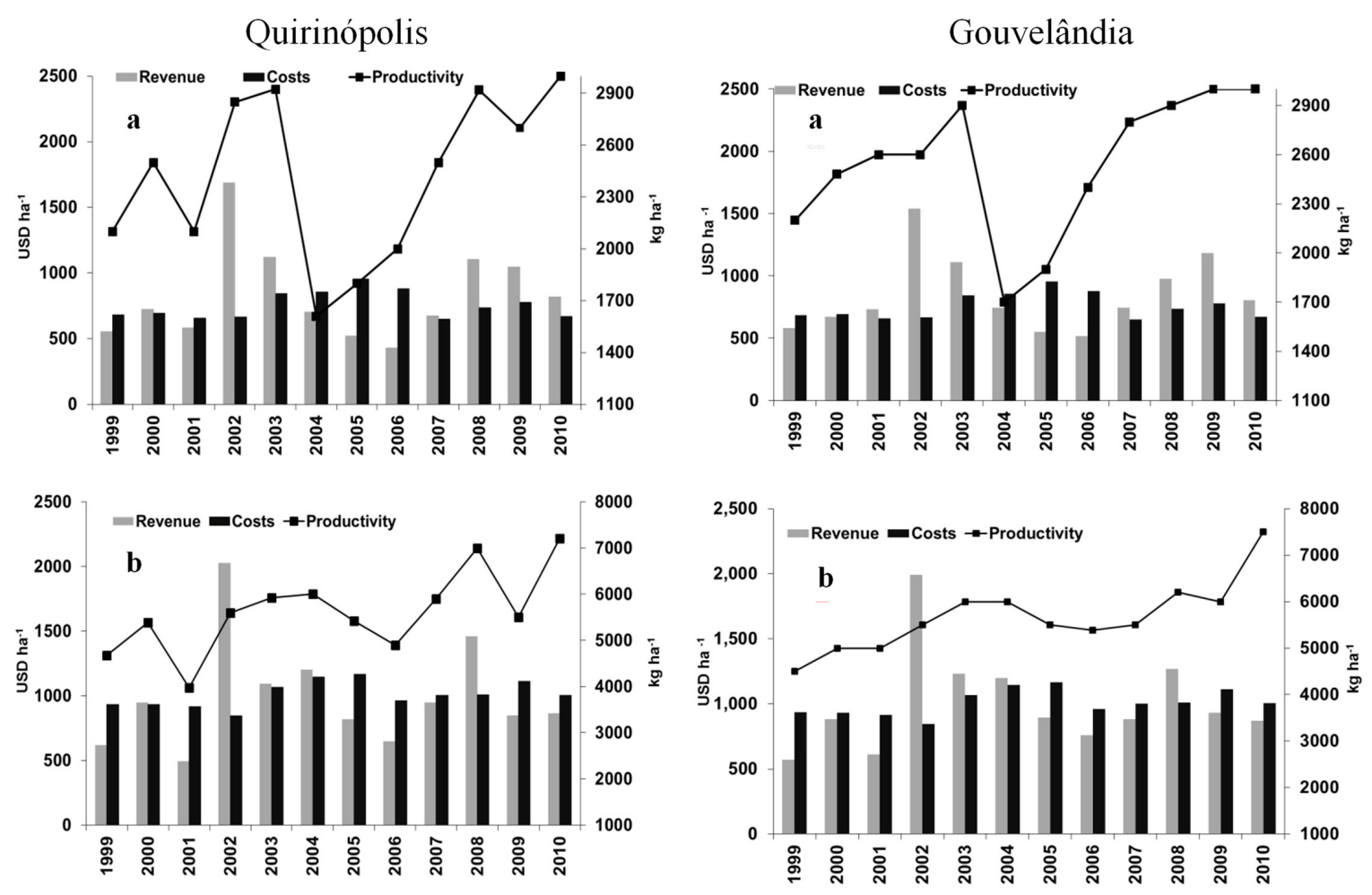

Figure 2 - Revenues, production costs and productivity of soybean (a) and maize (b) over a period of 11 years in the municipalities of Quirinópolis and Gouvelândia, Goiás, Brazil. Sources: estimated from data provided by IBGE (2012) and CONAB (2012). Revenues and production costs were inflation corrected (IPCA) in Reais (R\$) and converted to US dollars (USD $1=\mathrm{R} \$ 1.8$, average exchange rate in 2010).

\section{FIELD ASSESSMENT OF SUGARCANE EXPANSION}

In the second survey, we identified the type of land use before the advent of sugarcane cropping in 54 areas covering 30,408 ha (Table II), representing $57 \%$ of the total area cropped with sugarcane in Quirinópolis and Gouvelândia in 2010 (CANASAT 2013). Of these 30,408 ha of sugarcane, $45.7 \%$ $(13,906 \mathrm{ha})$ were pastures before replacement by sugarcane, $31 \%$ ( $8,016 \mathrm{ha})$ were pastures rotated with soybean or maize and $23.3 \%(8,486$ ha) were cropped only with soybean or maize. Surveyed areas of less than 200 ha were part of larger farms; some had been used as trials for future expansion of sugarcane while others were investments, in which the owner lived in the city or elsewhere and had another sources of incomes. These investor farms were not included as small farms in this study.

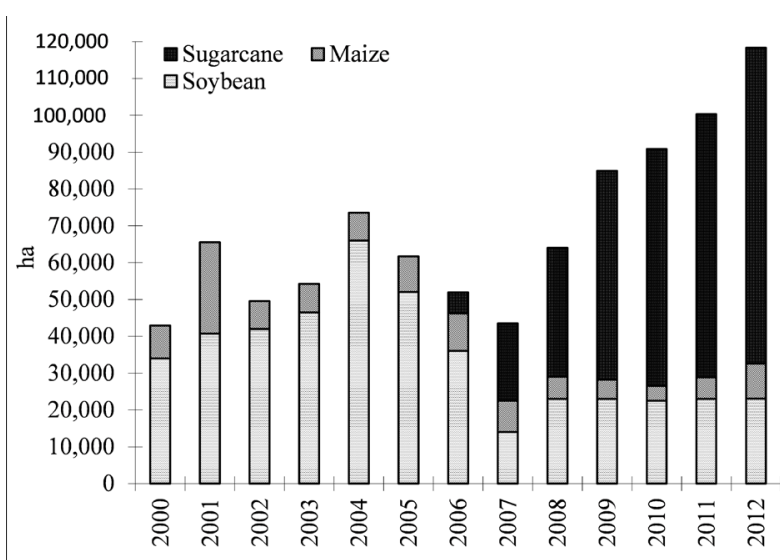

Figure 3 - Soybean, maize and sugarcane cropped area in Quirinópolis and Gouvelândia municipalities, Goiás, Brazil. Source: IBGE (2012), CANASAT (2013). 
TABLE II

Past land use in areas currently under sugarcane in the counties of Quirinópolis and Gouvelândia, Goiás, Brazil (n = 54; area $=30,408$ ha).

Land use before sugarcane*

\begin{tabular}{|c|c|c|c|c|c|}
\hline \multicolumn{2}{|c|}{ Pasture } & \multicolumn{2}{|c|}{ Cropping } & \multicolumn{2}{|c|}{ Pasture and cropping } \\
\hline Farm & Area (ha) & Farm & Area (ha) & Farm & Area (ha) \\
\hline 1 & 38 & 1 & 38 & 1 & 240 \\
\hline 2 & 96 & 2 & 77 & 2 & 336 \\
\hline 3 & 96 & 3 & 120 & 3 & 480 \\
\hline 4 & 96 & 4 & 134 & 4 & 576 \\
\hline 5 & 115 & 5 & 168 & 5 & 720 \\
\hline 6 & 144 & 6 & 168 & 6 & 1,334 \\
\hline 7 & 168 & 7 & 192 & 7 & 2,400 \\
\hline 8 & 192 & 8 & 192 & 8 & 2,400 \\
\hline 9 & 240 & 9 & 211 & - & - \\
\hline 10 & 288 & 10 & 288 & - & - \\
\hline 11 & 288 & 11 & 288 & - & - \\
\hline 12 & 293 & 12 & 336 & - & - \\
\hline 13 & 350 & 13 & 336 & - & - \\
\hline 14 & 384 & 14 & 461 & - & - \\
\hline 15 & 398 & 15 & 518 & - & - \\
\hline 16 & 413 & 16 & 528 & - & - \\
\hline 17 & 432 & 17 & 701 & - & - \\
\hline 18 & 451 & 18 & 802 & - & - \\
\hline 19 & 480 & 19 & 960 & - & - \\
\hline 20 & 480 & 20 & 1,498 & - & - \\
\hline 21 & 614 & - & - & - & - \\
\hline 22 & 710 & - & - & - & - \\
\hline 23 & 1,382 & - & - & - & - \\
\hline 24 & 1,498 & - & - & - & - \\
\hline 25 & 2,098 & - & - & - & - \\
\hline 26 & 2,160 & - & - & - & - \\
\hline Total area & 13,906 & & 8,016 & & 8,486 \\
\hline
\end{tabular}

*These areas represent one or more fields cropped with sugarcane within a farm, and not necessarily the total farm area. Farms with less than 200 ha under sugarcane whose owners live in the city with other sources of incomes are not considered small farms in this study. 


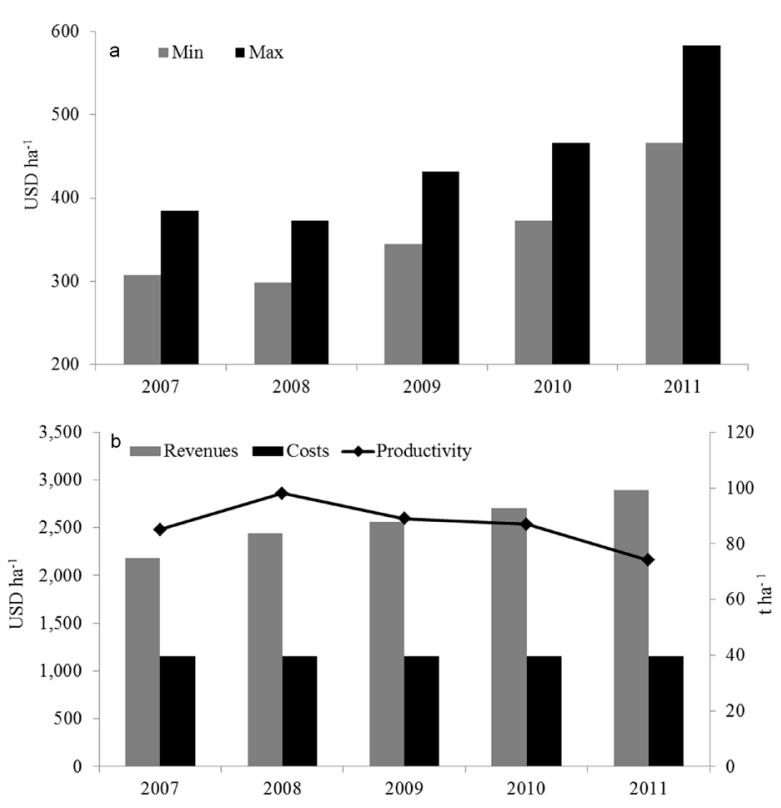

Figure 4 - Sugarcane profitability of farmers for payment contracts under land lease (a) considering the TRS (Total Recoverable Sugar) in 12 or 15 tons of sugarcane per hectare or for independent suppliers (b) in the municipalities of Quirinópolis and Gouvelândia, Goiás, Brazil. Sources: estimated from IBGE (2012); Consecana (2012). Revenues and production costs were inflation corrected (IPCA) in Reais (R\$) and converted to US dollar (USD 1 = R\$ 1.8).

Moreover, we estimated (data not shown) that sugarcane mills own only 2,500 ha of sugarcane in these counties all together.

Although most sugarcane expansion took place over former pastures, there was also an important element of replacement of soybean and maize cropped areas. In Quirinópolis and Gouvelândia, pastures occupy five times more land than soybean and maize; however, according to our survey, the proportion of area under pasture converted to sugarcane compared to that of soybean and maize was 2:1 between 2005 and 2010. Other studies carried out in the same region (Abdala and Ribeiro 2011, Ferraz et al. 2013, Barbalho et al. 2013), have reached similar results: Sugarcane mostly replaces grain crops, demolishing the perception that sugarcane is mainly replacing degraded pastures.

\section{CONCLUSIONS}

Farmers' decision to shift or not to shift to sugarcane cannot be explained simply by the existence of degraded pastures that could be repurposed. Instead, sugarcane cropping is related to farm size, lower risk as perceived by farmers, and higher profitability of sugarcane compared with soybean and beef cattle in the studied region. Of 30,408 ha under sugarcane surveyed in 2010, $45.7 \%$ used to be pastures before sugarcane introduction, 31\% was pastures rotated with soybean and maize, and $23.3 \%$ was cropped exclusively with soybean or maize. Sugarcane was not found to put dairy farmers or other smallholders out of business. Restrictions due to environmental law, dismantling of infrastructure, loss of assets, loss of autonomy over their land, and undesired lifestyle changes are among the reasons for dairy cattle's resilience in Quirinópolis and Gouvelândia counties.

\section{ACKNOWLEDGMENTS}

We are grateful to the Agência Goiana de Assistência Técnica, Extensão Rural e Pesquisa Agropecuária, EMATER-GO/Quirinópolis, especially to Carlos Ulisses Leal Brito, for their support of our data collection and fieldwork. We are also grateful to all of the farmers interviewed for their cooperation.

\section{REFERENCES}

ABDALA K AND RIBEIRO LF. 2011. Análise dos impactos da competição pelo uso do solo no Estado de Goiás durante o período 2000 a 2009 provenientes da expansão do complexo sucroalcooleiro. RBE 65: 373-400.

BARBALHO MGS, SILVA AA AND CASTRO SS. 2013. A expansão da área de cultivo da cana-de-açúcar na região sul do Estado de Goiás de 2001 a 2011. RBCIAMB 29: 98-110.

BARBOSA-FILHO NJ. 2008. Inflation Targeting in Brazil: 1999-2006. International Review of Applied Economics 22: $187-200$.

BARCELOS AO. 1996. Sistemas extensivos e semi-extensivos de produção pecuária bovina de corte nos Cerrados. In: Simpósio sobre os cerrados, 8. International symposium on tropical savanas, 1.Brasília. Biodiversidade e produção 
sustentável de alimentos e fibras nos Cerrados. Anais Planaltina: EMBRAPA-CPAC, p. 130-136.

CANASAT - MAPEAMENTO DA CANA VIA IMAGENS DE SATÉLITE DE OBSERVAÇÃO DA TERRA. 2013. Disponível em: www.dsr.inpe.br/canasat.

CEPEA - CENTRO DE ESTUDOS AVANÇADOS EM ECONOMIA APLICADA. 2012. Escola Superior de Agricultura "Luiz de Queiroz" Universidade de São Paulo. Agromensal. Disponível em: www.cepea.esalq.usp.br/ agromensal.

CGEE - CENTER FOR STRATEGIC STUDIES AND MANAGEMENT. 2012. Sustainability of sugarcane bioenergy. Brasilia, DF. 336 p. Available at http://www. unica.com.br/documentos/publicacoes.

CONAB - COMPANHIA NACIONAL DE ABASTECIMENTO. 2012. Custos de produção - culturas de verão. Disponível em: www.conab.gov.br.

CONSECANA - CONSELHO DOS PRODUTORES DE CANA-DE-AÇÚCAR, AÇÚCAR E ÁlCOOL DO ESTADO DE SÃO PAULO. 2006. Manual de Instruções. Disponível em: www.consecana.com.br.

CONSECANA - CONSELHO DOS PRODUTORES DE CANA-DE-AÇÚCAR, AÇÚCAR E ÁLCOOL DO ESTADO DE SÃO PAULO. 2012. Dados Históricos. Disponível em: www.consecana.com.br.

FERRAZ RPD, SIMÕES M AND DUBREUIL V. 2013. Indicadores para a avaliação do processo de expansão da cultura canavieira no sul do Estado de Goiás. RBCIAMB 29: 76-86.

HECHT SB 1993. The logic of livestock and deforestation in Amazonia. BioScience 23: 687-695.

IBGE - INSTITUTO BRASILEIRO DE GEOGRAFIA E ESTATÍSTICA. 2010. Indicadores de Desenvolvimento Sustentável. Estudos e Pesquisas. Informação Geográfica. Disponível em: www.ibge.gov.br/home/geociencias/ recursosnaturais/ids/ids2010.pdf.

IBGE - INSTITUTO BRASILEIRO DE GEOGRAFIA E ESTATÍSTICA. 2012. SIDRA - Sistema IBGE de Recuperação Automática, Banco de Dados Agregados. Disponível em: www.sidra.ibge.com.br.

IBGE/EMBRAPA - INSTITUTO BRASILEIRO DE GEOGRAFIA E ESTATÍSTICA/ EMPRESA BRASILEIRA DE PESQUISA AGROPECUÁRIA. 2001. Mapa de Solos do Brasil. Escala 1:5.000.000, Rio de Janeiro.

IEA - INSTITUTO DE ECONOMIA AGRÍCOLA. 2012. Banco de Dados. Disponível em: www.iea.sp.gov.br/out/ index.php.

INMET - INSTITUTO NACIONAL DE METEOROLOGIA. 2012. Climatologia. Disponível em: http://www.inmet. gov.br/html/clima.php\#.

KICHEL AN, MIRANDA CH AND ZIMMER AH. 1999. Degradação de pastagens e produção de bovinos de corte com a integração agricultura x pecuária. In: Simpósio de produção de gado de Corte, 1., Viçosa. Anais...Viçosa, MG: UFV, p. 201-234.

MANZATTO CV, ASSAD ED, BACCA JFM, ZARONI MJ AND PEREIRA SEM (Orgs). 2009. Zoneamento Agroecológico da Cana-de-Açúcar - Expandir a produção, preservar a vida, garantir o futuro. (Documentos 110). Disponível em: www.cnps.embrapa.br/zoneamento_cana de_acucar/ZonCana.pdf.

MDS - MINISTÉRIO DO DESENVOLVIMENTO AGRÁRIO. 2009. Agricultura familiar no Brasil e o censo agropecuário de 2006. Disponível em: http://www.mda. gov.br/portal/publicacoes.

MIGUEL FB, ESPERANCINI MST, GRIZOTTO RK, BARBARO IM, SILVA JAA AND SIQUEIRA RS. 2011. Análise de rentabilidade e risco na produção de cana-deaçúcar na região norte do estado de São Paulo sob dois tipos de arranjos contratuais. Revista Energia na Agricultura 26: 21-38.

MIRANDA CHB. 2001. Ciclagem de nutrientes em pastagens com vistas à sustentabilidade do sistema. In: Herrero $\mathrm{M}$ and Ramírez A (Eds), Manejo y evaluación de pasturas tropicales. Santa Cruz: CIAT, p. 95-108.

O ESTADO DE SÃO PAULO. 2011a. Sai o pasto degradado, entra lavoura. Jornal online - Economia e Negócios, 28 de setembro de 2011. Disponível em: http://www.estadao. com.br/noticias/impresso,sai-o-pasto-degradado-entralavoura-,778554,0.htm.

O ESTADO DE SÃO PAULO. 2011b. São Martinho e Petrobrás Bio investem R\$ 520 mi na Usina Boa Vista. Jornal online - Economia e Negócios, 17 de agosto de 2011. Disponível em: http://economia.estadao.com.br/ noticias/negocios\%2Benergia,sao-martinho-e-petrobrasbio-investem-r-520-mi-na-usina-boa-vista,80578,0.htm.

SEABRA JEA AND MACEDO IC. 2011. Comparative analysis for power generation and ethanol production from sugarcane residual biomass in Brazil. Energy Policy 39: 421- 428.

TROSTLE R, MARTI D, ROSEN S AND WESTCOTT P. 2011. Why have food commodity prices risen again? A report from the Economic Research Service-USDA. Available at: http://www.ers.usda.gov/publications/wrs1103/.

WTO - WORLD TRADE ORGANIZATION. 2005. European communities: Export subsidies on sugar. Available at: www. wto.org/english/tratop_e/dispu_e/cases_e/ds266_e.htm.

YOKOYAMA LP, VIANA FILHO A, BALBINO LC, OLIVEIRA IP AND BARCELLOS AO. 1999. Avaliação econômica de técnicas de recuperação de pastagens. Pesqui Agropec Bras 34: 1335-1345.

ZOPELARI ALMS AND TEIXEIRA SM. 2011. O papel determinante do investimento empresarial e subsídios fiscais na expansão do agronegócio canavieiro no estado de Goiás (2007-2010). Conjuntura Econômica Goiana 18: 52-62. 